\title{
AN HISTORICAL OVERVIEW OF CRIME PREVENTION INITIATIVES IN CANADA: A FEDERAL PERSPECTIVE
}

\author{
Michel Vallée
}

\begin{abstract}
The author provides an historical overview of crime prevention activities in Canada that have led to the federal government's current direction in crime prevention policy. Drawing on more than 30 years experience as a federal public servant with the Ministry of the Solicitor General and Justice Canada, the author traces more than 100 years of Canadian federal crime prevention efforts, with an emphasis on both internal and external government documents and historic material from the Royal Canadian Mounted Police. This brief history of crime prevention efforts in Canada shows a clear trajectory from the mid-1980s onward, towards support for more comprehensive and integrated communitybased crime prevention activities. The interventions are increasingly aimed at community safety, health, and well-being while involving the police, other service providers, as well as community members in the process.
\end{abstract}

On July 5, 2001, the Government of Canada announced an investment of \$145 million in the National Strategy on Community Safety and Crime Prevention (referred to as the National Strategy). This funding added to the National Strategy's previous allocation of $\$ 32$ million per year. The Government of Canada reported that this additional funding fulfilled a promise in the Speech from the Throne, which had committed the federal government to strengthening its effort to support communitybased responses to crime. The federal expectation was that this new funding would increase the National Strategy's capacity to provide communities with the knowledge, tools, and support mechanisms required to address some of the root causes of crime and victimization.

Some view the government's actions as the culmination of years of various federal efforts and reflection upon more effective ways to deal with crime and victimization. The focus in this article is to provide an historical overview of crime prevention activities in Canada that have led to the federal government's current direction in crime prevention policy. While the present article provides a brief historical portrait of Canadian crime prevention efforts, the focus is on federal involvement in crime prevention. For the most part, the focus is on activities under the direct responsibility of the federal Department of Justice (Justice Canada) and the then Ministry of the Solicitor General of Canada (MSG), presently called Public Safety and Emergency Preparedness Canada. Other departments have also supported crime prevention initiatives, such as: Health Canada; Heritage Canada (and its predecessor the Secretariat of State); Human Resources and Development Canada (and its 
predecessor Employment and Immigration Canada); the Department of Indian and Northern Affairs; and Status of Women Canada. These departments, however, have never had a formal lead policy role, nor have they formally documented their specific involvement in crime prevention, except possibly very recently. These departments have provided information, support, and resources to victim services and advocacy groups across the country through several major federal policy initiatives such as the Victims of Crime, Child Development, and the Family Violence Initiatives, among others.

It should be noted that describing the Canadian experience in crime prevention through the eyes of the national federal government, constitutionally responsible for the criminal law, does not negate the important and critical role that provincial or territorial and municipal governments have played over time. For example, provincial and municipal police forces have made important contributions to crime prevention across Canada.

While this analysis of more than 100 years of Canadian federal crime prevention efforts represents only a partial picture of crime prevention activities in Canada, it does reference a vital part of those activities. Most of the information introduced in this chapter comes from the following sources: the author's work experience, which spans more than three decades in both the MSG and Justice Canada; many informal internal documents that do not lend themselves to formal referencing; and formal internal and external publications. In reviewing the material for this chapter, it soon became evident that the annual reports of the two key departments and their agencies offered little information on crime prevention activities prior to 1970. However, the RCMP Quarterly provided useful and consistent information on federal policing and crime prevention work. The article is therefore, divided into five key historical periods:

1. The Early Years (up to the mid-1960s);

2. The Police-Community Relations Era (mid-1960s to mid-1970s);

3. The Community Crime Prevention Era (mid-1970s to mid-1980s);

4. The Policy Development Era (mid-1980s to the early 1990s); and

5. The New Directions Era (mid-1990s to the present day).

\section{The Early Years: Up to the Mid-1960s}

Until the mid-1960s, there is little readily available information on early federal crime prevention efforts within the Department of Justice or the Ministry of the Solicitor General of Canada. It should be remembered that the Ministry of the Solicitor General did not exist during the early years. Early efforts are implicitly linked to the work done by the Royal Canadian Mounted Police (RCMP) and its predecessors, the Royal North West Mounted Police (RNWMP) and the Dominion Police.

The law enforcement system in Canada originated in its colonial structure. Prior to Confederation, territories or quasi-colonies, such as "la Nouvelle-France”, then later 
Nova Scotia, New Brunswick, Québec, and Ontario, relied primarily upon the military to patrol their towns and cities. Dickson (1987, as cited in Griffiths \& Verdun-Jones, 1994, p. 56) indicates that the first police officers were deployed on the streets of Québec City in 1651. After the conquest of Nouvelle-France by the British in 1759, the Governor and his Council adopted law-making and law enforcement roles.

It was not until after Confederation in 1867, in particular the late 1800s, that organized police forces were established. Sheriffs, police chiefs, and constables reported to locally elected or appointed officials. In some parts of the country, the provinces stepped in and created Boards of Commissioners of Police. Generally speaking, it was only after World War I that Canada appeared concerned about having one national police force. Thus, in 1920, the Royal North West Mounted Police became a force responsible for all of Canada through the absorption of the Dominion Police. The new force became known as The Royal Canadian Mounted Police (RCMP). The headquarters for the newly created force were relocated to Ottawa. The creation of the RCMP brought policing to rural Canada.

While there is little if any direct reference to preventive work (as we now define it) in the RCMP annual reports before the early 1960s, there are occasional references to preventive-type work with the Department of Interior in the Northwest Territories. In addition, there is frequent reference to the work of the Prevention Services Branch from its creation in 1932, to the latter part of the 1960s. Additionally, as far back as the 1930s there are numerous references in the Royal Canadian Mounted Police Quarterly to "prevention of crime and prevention work".

It is noteworthy to mention that the first reference to actual prevention work that the author was able to trace is found in 1897, with the creation of "Prevention Services" as a branch of the old Customs Department. Aside from protecting revenues, its "new" mandate was to patrol the lower Gulf of the St. Lawrence and the Atlantic seaboard. This early preventive force operated until 1921 on a small scale, when the Inland Revenue Department merged with the Customs Department forming the Department of Customs and Excise. Vernon (1936) mentions that Prevention Services was taken over by the RCMP in 1932, at which time its officers were given the additional power of the Customs and Excise Prevention Officers.

During the 1930s, we begin to find more documented information on crime prevention activities. One of the notable articles is found in the premier edition of the RCMP Quarterly, July 1933, authored by Prime Minister R. B. Bennett. Prime Minister Bennett states: "The history of the part played in the administration of justice by the Mounted Police proves that they are as intent on conciliation as on accusation; their efforts have been almost as much devoted to the prevention of disputes and of crime as to the apprehension of those who have broken the law" (Bennett, 1933).

During this period, crime prevention is also associated with the advent of new equipment and technology. During the 1930s, many articles in the RCMP Quarterly 
refer to the preventive role of police in relation to the acquisition and use of patrol boats, cruisers, and aeroplanes, as well as technical advances such as fingerprinting and automobile tire marking. There are a few references to the so-called causes of crime, both biological and environmental, in addition to the need to prosecute criminals for the purpose of preventing more crimes and the need to seek the help of local citizens in identifying the distinctive operating methods of criminals. The need to identify criminals' operating methods becomes a topic of discussion during the second half of the 1930s.

The Prevention Services Branch of the RCMP appears to be the only section to have a formal prevention mandate during this era, primarily interested in preventive work as it pertained to the question of "revenues". Kelly and Kelly (1973) note that much of the prevention effort was spent on reducing or eliminating bootleggers and smugglers (called "rum-runners"). This concern over the "revenue” side of governmental operations continues to the mid-1960s. At this time, the RCMP still had full responsibility for the administration of the following federal statutes: the Customs Act, the Excise Act, the Income Tax Act, the Canada Shipping Act, and the Estate Tax Act (Government of Canada, 1967).

Prevention efforts during the 1940s are marked by three themes: (a) the prevention of juvenile delinquency; (b) the prevention of possible sabotage, as well as the counterfeiting of money, gas, and food coupons during the war years; and (c) the post-war prevention and detection of Soviet espionage. Delinquency prevention and youth crime topped the RCMP list of preoccupations during this period. A number of articles in the RCMP Quarterly highlight a variety of issues pertaining to juvenile delinquency. Crime causation and acting out appear to form the basis of the Force's concern. They were also concerned with the most opportune time to take preventive measures. There are references to such factors as: home environment; mental development; not being able to attend school; facing unemployment; and the "dangerous years" for youth crime (identified here as between 15 and 21 years of age). In 1940, RCMP Constable L. Binham suggests: "The policeman should be a guiding force in the life of the youth, encouraging his interests in sports and constructive worthwhile subjects, at the same time instilling in the minds of the youth a respect for the rights and property of others as well as a clean sense of values” (Binham, 1940).

We begin to see a desire to promote an education and reformation role within juvenile courts, rather than the strictly punitive role the courts were taking in dealing with young persons. Prevention becomes linked to rehabilitation, which was also now associated with psychological factors, called "appetites” (e.g., thirst, hunger, and sex); there are also references to "attitudes" (e.g., withdrawing and approaching), emotions (e.g., fear, rage, and love), and self-tendencies (e.g., negative and positive). We also note an early interest in what some referred to as "petty crimes" (Wilson, 1942). For example, a concern about shoplifting (then called "boosting") was discussed, as well as the means of preventing and apprehending shoplifters. 
By the mid-1940s, the RCMP (sometimes referred to as the "Force") becomes more articulate about the causes of youth crime and the means to prevent or reduce such crimes. With the advent of the "Youth and Police Movement", the RCMP began to promote a number of programs and approaches with the aim to decrease the amount of juvenile delinquency. The Force became concerned about “urban youth”. Local constables were encouraged to be role models for youth through engaging in such local activities as coaching boys in sports, assisting as scout masters, and helping out at the local church. The RCMP philosophy about youth is eloquently summarized in the following quote:

Today more than ever before, Canada's cities are awakening to the need for teen-age centres of recreation, places more conducive to the young person's well-being and more enticing than juke joints and cheap cafes and dance halls, where our young people are given the opportunity not only to associate with others of their own age but to develop their talents along lines in which they have aptitudes (Moore, 1945).

During the 1940s, we see an increasing belief that a youth's environment has a significant impact upon future criminality; and toward the end of the 1940s, references are made to the new concept of the "suburb" as a collection of homes, churches, schools, and stores. In this context, references are also made to drugstores with soda fountains and to "bobby-soxers" with their male counterparts. During this time of social, moral, and technological change, the RCMP began to perceive that technological advances could serve as tools in preventing crime. This was particularly true of the new radio telephone. During the early 1940s, equipping police cars in Western Canada with radio telephones was viewed as so successful in increasing policing efficiency and reducing crime that it quickly expanded. The policing trend of "youth recreation" continued throughout the 1950s, while concurrently dealing with other social dilemmas such as increasing drug trafficking and the "management" of post-war European immigration. These represented challenges for the policing of urban areas.

With the publication and national distribution (in both English and French) of an illustrated booklet entitled, Crime In Your Community, the Force began expanding its public communication efforts attempting to reach the broader public. In particular, it sought the cooperation of householders, merchants, and businessmen in crime prevention. Kelly and Kelly (1973) note that the demand for these booklets far exceeded the supply; soon, a second booklet, was published and distributed (called Beware of Bad Checks). Thus began a new era of community-focused crime prevention efforts for the RCMP. It is not until the mid-1960s, however, that such policing efforts become formalized.

Kelly and Kelly (1973) suggest that from the mid-1950s to the late 1960s, the Force's primary concern is drug trafficking (both hard and soft drugs), organized crime, 
white-collar crimes, spies, politics, and security. Consequently, a general crime prevention focus appears to have taken a back seat to these priorities. When prevention activities do take place, they are directed to prevent the aforementioned types of crime. This conclusion is reinforced by an analysis of the Report of the Proceedings of what appears to be the "first" National Conference on the Prevention of Crime, convened from May 31 to June 3, 1965, by the University of Toronto's Centre of Criminology, in collaboration with the Conference of the Chief Justices of Canada. Of interest, the formal list of participants includes judges, federal and provincial justice or attorney general legal representatives, academics, a few politicians, the Deputy Commissioner of the RCMP, and the Commissioner of the Ontario Provincial Police (OPP). As well, police representatives were in attendance from several major cities including Vancouver, Regina, Toronto, Hamilton, Montréal, Moncton, and Halifax.

Three key issues were identified at the beginning of the conference: First, all the available evidence pointed to a continuing increase in the amount of indictable crime committed across Canada. Second, there was a realization that society was faced with the sobering fact that in the area of crimes against property, the forces of criminal law had, for several years, fallen further and further behind in bringing malefactors to account for their misdeeds. Third, a mounting concern was expressed by the country's senior police officers, both in public and more vividly in their annual reports, as to their ability to keep up with, let alone get on top of, the growing number of indictable offences (Centre of Criminology, 1965, pp. 7-8).

Does this sound familiar - if not the terms at least the ideas? A reading of the agenda gives an indication of the interest in assessing police relationships with the public and the general attitudes of ordinary citizens toward the police. A review of the agenda indicates that only one portion of the conference's first day was devoted to specific discussions on crime prevention. The conference organizers' statement to the press, suggests at least three key conclusions: First, citizen rights must necessarily involve attention being given to each person's commensurate responsibility for the safety and protection of his neighbours in society; second, there is a question of to what extent the changing picture of crime in our modern society requires a lessening of the insistence on the inviolable maintenance of the individual's rights and privileges in order to secure greater protection for society as a whole; and, third, the discussion groups gave some consideration to the question of whether some restrictions should be placed on the reporting of court proceedings in the news media during the preliminary hearings of indictable offences (Centre of Criminology, 1965, pp. 69-72).

It appears that the conference proceedings reflected the preoccupations of the day, similar to concerns and issues expressed in several articles (cited previously) written for the RCMP Quarterly during the 1950s and 1960s. Participants at the conference did, however, reach a consensus concerning the increase in crime and the fact that youth play a significant role in this increase. Participants also agreed on the role played by some of the social changes occurring, namely, increased urbanization, the lack of family and religious ties, the disparity between the "haves and the have-nots" of 
society, and the lack of responses available to youth courts. These social changes are cited as sources of the increase in indictable offences. Concerns begin to be raised about the increase in negative public perceptions and attitudes toward the police. According to conference participants, the media is a contributing factor in these negative perceptions.

Finally, since few of the participants came from non-judicial or non-legal backgrounds, it is difficult to ascertain the full impact of the conference discussions upon the direction taken in subsequent federal policy. This is a period where there is little federally focused or federally sustained interest in policy relating to crime control issues. The exception, of course, is the RCMP.

\section{The Police-Community Relations Era: Mid-1960s to Mid-1970s}

Beginning in the early 1960s and through to the mid-1970s, there are numerous references to the Prevention Services Branch of the RCMP. These references are found in either the RCMP Gazette or RCMP annual reports. The work of the Branch, however, appears to have little to do with the more recent views on crime prevention; "crime prevention" meant dealing with the administration of federal statutes such as the Customs Act, the Excise Act, the Income Tax Act, the Canada Shipping Act, and the Estate Tax Act. It is rare to find any direct reference to crime prevention in the RCMP Gazette and the RCMP annual reports. The last reference to crime prevention in the Force's annual reports is in 1961 under the heading, "Other Investigative and Administrative Assistance". It reads as follows: "Work of a preventive and educational nature such as inspection of explosives, magazines, certain drugstores and hospitals, public buildings (for Provincial Fire and Safety Regulations), conducting anti-safe breaking and preventive services patrols, and escorting prisoners or mental patients for other police forces” (Government of Canada, 1961, p. 21).

With regard to the Ministry of the Solicitor General of Canada (MSG) ${ }^{1}$ there is reference to prevention in its early years, though it is couched implicitly in terms of youth delinquency and support for the work being done by the Committee on Juvenile Justice, then under the authority of the Department of Justice Canada. The creation of the Correctional Consultation Centre (CCC) during the 1968-69 fiscal year appears to signal the beginning of a federal interest in crime prevention. The CCC was first located in the Departmental Headquarters (DH) of the then Ministry of the Solicitor General of Canada and was subsequently integrated into the Ministry Secretariat as the Consultation Centre in 1973-74. The CCC's mandate highlighted the need to gather and disseminate information on prevention and the need to support "demonstration projects" aimed at implementing new methods in the prevention of crime. Greater attention to public involvement and youth in police training was now emphasized. A reading of the MSG's annual reports during this period indicates a strong push for police-community relations, with an emphasis on the youth population. Several major demonstration projects focusing on the role of the police in schools received funding from the MSG. 
A review of the policy mandate of the MSG's Correctional Consultation Centre suggests "finding solutions to a recognized set of problems is the federal field of responsibility consistent with the objectives of achieving sound social defence measures, i.e., the protection of society and rehabilitation of the offender" (Government of Canada, 1971, p. 7). This was slowly becoming a high policy priority for the federal government.

There appears to be little change in direction or interest, however, on the part of the MSG during the first half of the 1970s. Youth and police-community relations continue to be the focal point for demonstration projects and research. Some financial investments were made in prevention programs aimed at youth and the police by the MSG's Correctional Consultation Centre. One example is the funding provided to the Montréal YMCA, in order to assess the value of a street-work approach to reducing juvenile delinquency. Funding was also provided for three conferences, considering the community role and training and research requirements related to "The Police Function in Our Changing Society” (Government of Canada, 1973).

\section{The Community Crime Prevention Era: Mid-1970s to Mid-1980s}

In the mid-1970s, we begin to see some federal efforts to understand what is actually happening in the area of crime prevention, particularly by examining the types of crime prevention efforts being promoted in the United States and the United Kingdom. In addition, we observe the beginnings of a leadership role on the part of the MSG's Ministry Secretariat. Several pilot projects were funded (for example, there were some relating to Crime Prevention through Environmental Design and target hardening). As well, a major team policing/zone-policing project was funded in Burlington, Ontario. These efforts, and the apparent desire to expand its involvement in crime prevention, led the MSG to provide funding to the University of Toronto's Centre of Criminology for the first comprehensive National Crime Prevention Workshop, held May 21 and 22, 1975.

Gordon Watson set the tone at the start of the conference (which the author attended), by stating that the conference's purpose was "to review developments in the field of crime prevention over the last ten years; to assess these new developments in terms of both their efficacy and their ethics; and, to establish research priorities for the years to come" (Watson, 1975, p. v). Assessing the nature and scope of conference participants and range of topics discussed, it appears that it did indeed make a significant contribution to the future direction of crime prevention in Canada.

B. C. Hofley, Assistant Deputy Minister, Ministry of the Solicitor General of Canada, presented the federal position on crime prevention. Mr. Hofley asked the participants, "to join the federal government in making a commitment to the cause of crime prevention so that together we can work towards a reduction in the overall social and economic costs of crime” (Hofley, 1975, p. 65). He suggested that the federal 
government was concerned about costs: the high costs of administering the criminal justice system; the costs of financial loss for victims; the costs of security and prevention measures in public institutions, private enterprises, and residences; costs of insurance; the loss of the wage earnings of confined offenders and incapacitated victims; and the consequent increased welfare burden imposed upon the families of those incarcerated.

Mr. Hofley (1975) went on to suggest greater investment in "front-end" interventions, which were to include diversion programs and more police training to promote a service and prevention orientation, both within the RCMP and other police forces. In addition, he highlighted the need to gain more knowledge about crime and its effects. It was thought that this could be accomplished through victimization surveys and by evaluating the effectiveness of crime prevention programs. He also made a link between prevention and the need to take a more concerted approach to young persons in conflict with the law. One cannot help but notice how similar these ideas are to recent debates on the cost and impact of crime and victimization to society. As we will see later, the issue of the cost of crime was part and parcel of the federal government's decision to launch the National Strategy on Community Safety and Crime Prevention in 1993.

Participants at the 1975 Conference on Crime Prevention identified the need for research in the area of urban design and crime prevention. The conference participants proposed a definition of crime prevention that included efforts to reduce the desire to commit and the opportunity for criminal activities, along with decreasing the extent to which the criminal justice system is used to deal with crime (Macfarlane, 1975, pp. 125-127).

Notwithstanding the "renewed" federal interest and related policy statement, what really appears to have had the most impact on the federal involvement in crime prevention is the introduction by the Solicitor General, on February 24, 1976, of the Peace and Security Program, introduced along with the MSG's Youth Employment Program. The Peace and Security Program led to the creation of the Preventive Policing Program later in 1976. This was the forerunner of what would later be referred to as the Solicitor General's Crime Prevention Initiative. It was located in the Ministry Secretariat and, for the first time, the federal government made public five measures designed to prevent the commission of crime (Government of Canada, 1976, pp. 5661):

- Development of a national clearinghouse of information on police programs;

- Development of training programs in community relations, crisis intervention, and preventive policing;

- Development and dissemination of model preventive policing programs;

- Promotion of Crime Prevention through Environmental Design; and

- The implementation of victimization surveys. 
The latter event was a significant expansion of the federal government's Youth Employment Program, which included the allocation of departmental-based resources for youth employment. The RCMP began to make extensive use of the Ministry's Summer Employment and Activities Program (SSEAP), by hiring special constables to work with regular members on a variety of crime prevention and general policing projects (Government of Canada, 1976, pp. 24-25).

It is in 1977-78, with the advent of the Federal Labour Intensive Program (FLIP), that the MSG and the RCMP receive significant resources to support summer students (their first priority) and unemployed youth (in the following year), under the Job Corps Program. These youth were engaged in crime prevention programs and policecommunity relations programs. The impact of this appears more important for the MSG's Secretariat, since it redistributed these resources through the funding of a large number of crime prevention projects. These projects were under the supervision of municipal and provincial police forces, as well as community organizations, and provided the impetus for supporting a number of community-neighbourhood crime prevention strategies such as Neighbourhood Watch, operation identification, "lock it and pocket the key", security check systems, seminars on the protection of business premises, and other programs all across the country. The 1986 Crime Prevention Initiative Evaluation Report states, "The Secretariat has been interested in Crime Prevention for many years, as was evident by the establishment of a Causes and Prevention Research Section in 1974. It was not until the Preventive Policing Program was initiated in 1976 that crime prevention begins to become a programming priority” (Government of Canada, 1986b, p. 2).

During this period, there is also an investment in projects that are early examples of situational crime prevention interventions, mainly with respect to such crimes as shoplifting and residential break and enter. The RCMP continued its community relations and community prevention emphasis, while also initiating other programs, such as youth and community involvement, youth safety, and school drug prevention, among others. In addition, during the latter part of the 1970s, both the RCMP and the MSG Ministry Secretariat began to test and implement programs that considered issues of domestic violence, crimes against children and the elderly, vandalism, crisis intervention, and victim awareness.

During the latter part of the 1970s, there is also an increasing provincial interest in crime prevention programming. While it is true that the Ministry Secretariat had an emphasis on crime prevention and was moving toward promoting and expanding community involvement by disseminating information and expanding some useful pilot programs to other communities, it is the provinces that took a leadership role in the actual development of crime prevention programs and services. Such a provincial role is confirmed in the 1986 MSG evaluation report, which essentially suggests that the provinces and citizens groups were taking a leadership role in the development of crime prevention activities (Government of Canada, 1986b). 
In the early 1980s, interest in crime prevention increased. There is a greater emphasis put on victims of crime and in particular, "wife assault victims" (as it was then called), as well as on children who were victims of sexual and physical abuse. Both the federal government and the provinces were experiencing increased pressure by victims' advocates and "experts" to give more attention to measures supporting the needs of victims of crime. While crime prevention activities may have initially been viewed as the logical "chapeau" for victims support programs, this changed with the publication of the 1984 Federal-Provincial/Territorial Task Force Report on Victims of Crime in Canada and the subsequent successful effort to develop a stand-alone Victims of Crime Initiative.

The introduction, by the MSG, of a National Crime Prevention Week and the Solicitor General Awards, led the way for an enhanced Crime Prevention Initiative launched in 1984-85 and 1985-86. This initiative focused on three major goals: (a) the development and promotion of policies and programs contributing to the reduction of crime and the impact of crime on Canadian society; (b) the development of a more effective, efficient and humane criminal justice system; and (c) increased public understanding of and participation in the criminal justice system (Doherty, 1986).

From the mid-1970s to the mid-1980s, federal crime prevention efforts were concentrated mainly on communicating crime prevention, opportunity reduction, and target hardening strategies. During the latter part of this period, the MSG was giving increased attention to finding appropriate ways to prevent youth from developing attitudes and behaviours "suggestive” of future delinquency. The apex of MSG crime prevention efforts appears during the first half of the 1980s. We see an emphasis on community policing and "specialized and targeted" crime prevention programs, although the specific nature and extent of these are difficult to trace in departmental documents. By its own admission, the MSG recognizes that:

Thus far the development in Canada of community policing and crime prevention has been uneven. Nor has there been complete acceptance of these approaches. There remain large pockets of resistance and even where crime prevention units have been created they are often under-resourced and viewed by the police as "dead ends” for career development. (Government of Canada, 1986c, p. 6).

To summarize, during this era of community crime prevention, there is limited federal interest in the assessment of these crime prevention measures. The possible exceptions are the few anecdotal, self-evaluation efforts that suggest, "the Program was very successful in the eyes of both students and Force members" (Government of Canada, 1977, pp. 23-24). As well, there are a few evaluations of demonstration projects such as the London Police-Family Court Crisis Intervention Unit. The limited interest in evaluation of crime prevention efforts is equally true for the Ministry Secretariat. It is primarily in 1986 that the then Office of Audit and Evaluation 
completed its first formal evaluation of the MSG crime prevention efforts (Government of Canada, 1986a).

\section{The Policy Development Era: Mid-1980s to Mid-1990s - Toward a Comprehensive Federal Policy on Crime Prevention}

The 1986 MSG evaluation report states that the Ministry’s crime prevention approach included research and development, awareness and information, as well as community and social development and coordination. On the surface, the community and social development and coordination approach appears to be more a statement of intent or a wish than a reality. In concrete terms, most of the high profile crime prevention activities focus around the National Crime Prevention Week, established in 1983, along with the Solicitor General Crime Prevention Awards, the National Crime Prevention Resource Centre, and the Partners in Prevention crime newsletter. The MSG did obtain additional resources for their crime prevention efforts, including sponsoring a National Conference on "Crime Prevention through Social Development”. A National Workshop on Crime Prevention through Social Development, organized by the Canadian Council on Social Development (CCSD) and the Canadian Criminal Justice Association (CCJA), with financial support from the Ministry of the Solicitor General Canada (MSG), was held in Hull, Québec, February 4 to 6, 1987. This conference brought together approximately 175 people - researchers, policy-makers, and practitioners - involved in criminal justice, social service, health, employment, education, and housing. The objective of the conference was to explore the concept of Crime Prevention through Social Development itself, as well as looking at current knowledge in the field. Consideration could then be given to future steps that should be taken to enhance a commitment to Crime Prevention though Social Development (Canadian Council on Social Development \& Canadian Criminal Justice Association, 1987, p. 1).

While the seed for a broadening of the federal policy interest and efforts relating to crime prevention appears to be sown by the MSG, a subsequent political decision in the latter part of 1986 paved the way for the formal transfer, on April 1, 1987, of federal policy responsibility for crime prevention to the federal Department of Justice (Justice Canada). This de facto transfer from the MSG to Justice Canada appears to lead to a "slow-down" in crime prevention efforts and to confusion in stated policy and program development efforts over the next few years. Little documented evidence on further policy and/or program activities pertaining to a social development approach is available from either MSG or Justice Canada during that period.

In the latter part of the 1980s and early 1990s, non-governmental organizations (NGOs), assisted by federal funding, provided much of the leadership in crime prevention activity. This was accomplished through several key national initiatives related to Crime Prevention through Social Development. These activities included the national workshop (referred to previously), as well as a variety of publications such as the report on the European and North American Conference on "Urban Safety and 
Crime Prevention” (held in Montréal, October 1989) and the report entitled, National Social Strategy for Crime Prevention for Canada, released in 1989. The Canadian Criminal Justice Association (CCJA) prepared this latter report, which was one of the initiatives signalling the importance of social programming in planning a comprehensive agenda for safer communities.

There is, however, documented evidence that federal crime prevention efforts involving both the MSG and Justice Canada were continuing, with a focus on supporting community crime prevention activities. As well, there are interdepartmental policy and program development initiatives, that are part of a crime prevention policy agenda, that deal with aspects of crime, including substance abuse, drinking and driving, and the sexual abuse of children, among others. Despite extant programs, federal crime prevention initiatives during this period appear somewhat diffuse and poorly coordinated, with little evidence or information on what really works. Hastings (1991) reports the following:

The conclusion to be drawn from the four evaluation reports that were reviewed is that, by 1987, the Ministry of the Solicitor General knew a great deal about how people felt about the way things were being done, but very little about whether it was having any impact on crime or the fear of crime in our communities. Much was known about how to plan and manage an initiative, and about how to implement specific projects, but there was less certainty about just what exactly needed to be done substantively in order to prevent crime. (Hastings, 1991)

From 1987 to 1993, federal crime prevention policy and program development efforts, particularly those of Justice Canada, appear to be influenced as much by external events as by internal forces. The limited number of policies and program development efforts that are documented in Justice Canada files support this conclusion. During this period, information is more anecdotal and its sources come principally from personal discussions and recollections.

One example of an influential external event occurred in October 1989. In 1989 as referred to previously, Canada hosted the European and North American Conference on Urban Safety and Crime Prevention. It was organized by the Federation of Canadian Municipalities (FCM), the European Forum on Urban Safety, and the U.S. Conference of Mayors, in collaboration with the Montréal Urban Community, five international organizations of cities, and more than 30 other partners. Agenda for Safer Cities (a document coming out of this conference) proposed concrete action to prevent property and violent crime, to reduce the demand for drugs, and to decrease the feeling of insecurity within cities. As well, there were suggestions and specific strategies given, based upon the concept of Crime Prevention through Social Development (Canadian Council on Social Development, 1990, p. 8). This conference both proposed and initiated the creation of the International Centre for the Prevention of Crime (ICPC). 
The 1992 Paris Conference subsequently followed the strategic Montréal conference on crime prevention. Again, Canada was an active participant. Coming out of the Paris conference was the suggestion that, among other things, “...governments declare a child and youth policy to promote community implementation of programs and services in education, including pre-school and head start programs, health, housing, drug use prevention, recreation, training, and employment” (Liberal Party of Canada, 1993). The conference also confirmed the initiative to invest in setting up the ICPC in Montréal. This occurred on September 11, 1994.

Amidst all of these activities, Justice Canada, and to a much lesser extent the MSG, continued to fund crime prevention projects. Most of the federally funded projects centred on the community and on young offenders, or focused on both youth and the community. During this period, Justice Canada significantly enhanced its policy development work. It stimulated inter-departmental and federalprovincial/territorial relations, and it began improving the coordination of activities related to crime prevention. For example, in February 1992, Justice Canada set up a working group called the Interdepartmental Committee on Crime Prevention. It was felt that the main objectives of the federal government's crime prevention policy should be: (a) to improve the unfavourable social and economic conditions that are linked to crime, such as poverty, unemployment, illiteracy, and racism; (b) to improve the ability to protect individuals and society by reducing opportunities for individuals to commit crimes; (c) to provide effective law enforcement in communities; and (d) to reintegrate offenders into the community as law-abiding citizens.

Another external force was the work of the House of Commons Standing Committee on Justice and the Solicitor General. From November 1992 to February 1993, this committee undertook a national study on crime prevention. The report, called Crime Prevention in Canada: Towards a National Strategy (the Horner Report), recommended that Canada develop and promote a national strategy to reduce opportunities for crime and to respond to underlying factors contributing to crime (Government of Canada, 1993c). In addition, the Horner Report recommended the promotion of a national strategy involving partnerships and information sharing among all levels of government, all agencies in the criminal justice system, as well as NGOs and special interest groups.

The Standing Committee also supported the “Safer Community Approach”. Here, the community is seen as the focal point for effective crime prevention activity by encouraging problem identification and resolution through inter-agency, citizen, and business community partnerships. The Horner Report also suggested that crime prevention strategies include activities such as reducing the opportunities to commit crime, engaging social development investment and community policing, and the continuing use of traditional legal measures. The committee further recommended an incremental federal investment of its share of the criminal justice system costs, recommending up to a 5\% increase over a five-year period. It is important to emphasize 
that Justice Canada officials were closely involved in and supportive of the work done by the Standing Committee.

As previously mentioned, Justice Canada had hosted a National Symposium on Community Safety and Crime Prevention on March 10 to 12, 1993. As stated by the then Minister of Justice and Attorney General of Canada, Pierre Blais:

The result was an exceptional consensus that lasting improvements can only be achieved through a partnership that involves many disciplines and sectors of society, and supports community action to address the causes of crime. Delegates expressed marked support for the Report of the Standing Committee on Justice and the Solicitor General entitled Crime Prevention in Canada: Toward a National Strategy. (Government of Canada, 1993a)

Mention should also be made of a report produced by the Ad Hoc Advisory Committee for a National Strategy on Community Safety and Crime Prevention, called Community Safety through Crime Prevention. The Ad Hoc Advisory Committee was created in order to continue the work begun at the Symposium. It submitted its report in October 1993, endorsing a community-driven approach to crime prevention, giving priority to the development of partnerships and coordination at all levels.

While Justice Canada was spearheading these efforts, the MSG was continuing to reflect on its role in crime prevention. In January 1993, a draft paper on the need for a national strategy on crime prevention was circulated internally. The internal working group that produced the paper suggested that, among other things, the MSG build upon the experience and success of the past while recognizing the gaps and limitations inherent in that experience. The paper not only identified the need for a national strategy on crime prevention and fear reduction but also offered suggestions as to how such a strategy might be developed. For example, it suggested a broadening of all leadership roles within the criminal justice system and the various levels of government. As well, it suggested that the private sector and the community also play a more significant role and that leadership was also required in order to identify gaps, recognize emerging trends in crime, and deal with cross-jurisdictional implications. It identified the need to manage a coordinated response by all partners in crime prevention (Government of Canada, 1993b, p. 7).

During this period, the RCMP was continuing its community crime prevention efforts, though not documenting these activities very well. With a few exceptions, such as the Police Vocational Ventures/Rovers Program in partnership with Scouts Canada, and the formation of Community Consultative Committees to enhance interaction between police and community, there are few direct references to crime prevention work in the RCMP's annual reports. 
It would be remiss, however, not to mention some of the other broad federal interdepartmental initiatives launched during this period, which, in the author's view, impacted the effort by Justice Canada and the MSG to develop a comprehensive crime prevention policy. Probably the best known of the federal strategies, all containing elements of crime prevention, are the Third Enhanced Victims of Crime Initiative (1987-1993), the Brighter Futures and Child Development Initiative (1992-1997), and the Family Violence Initiative (1988). Although it is not the objective of this chapter to describe and assess how these initiatives relate to crime prevention, it is important to recognize their existence and their subsequent influence on the development of a comprehensive, national, federal strategy on crime prevention.

In January 1994, the Government of Canada's Speech from the Throne included a commitment to take measures to address the needs of Canadians on the issue of community safety and crime prevention. In a 1995 Justice Canada Program Evaluation report, we read, "In his response to the Speech form the Throne, the then Minister of Justice and Attorney General of Canada, Allen Rock, indicated his support for crime prevention through social development and for the establishment of a Crime Prevention Council” (Government of Canada, 1994d, p. 3). In the following months, in order to foster the development of a National Strategy on Community Safety and Crime Prevention, Justice Canada (taking the lead role) and the MSG held a number of interdepartmental consultations. This was done at the federal level through the previously referenced working group and a steering committee composed of assistant deputy ministers. Additionally, a number of federal-provincial/territorial consultations occurred, including discussions on a future National Crime Prevention Council. This was to be facilitated by means of a federal-provincial/territorial working group that would meet with a committee of deputy ministers and Ministers Responsible for Justice.

These federal efforts culminated in a document called, Outline of the National Strategy on Community Safety and Crime Prevention (Government of Canada, 1994b). This document described the progress achieved in developing six key elements for the National Strategy on Community Safety and Crime Prevention including:

- Coordination and communication;

- Public education and awareness;

- Project development;

- Research and evaluation;

- Legislative reform; and

- Mandates and funding.

In the report, cooperation with the jurisdictions was deemed important, especially in light of their responsibilities for service sectors, which have a great impact on community safety and crime prevention (e.g., health, education, social services, administration of justice, municipal affairs, and others). The result of all these federal 
efforts led to the May 1994 announcement, by the federal Cabinet, of its approval of a comprehensive National Strategy on Community Safety and Crime Prevention.

Provinces were also quite active and several provinces began developing and implementing their own provincial crime prevention programs and policies with a social development orientation. For example, all provinces and territories implemented and supported a crime prevention week. Many provinces were actively promoting strategies aimed at preventing crime and victimization. Three examples are:

In New Brunswick, a number of initiatives to prevent and reduce all forms of family violence, in operation since 1987 (Government of New Brunswick, 1997, p. 3); In April 1994, the Manitoba Attorney General, James C. McCrae, brought forward a discussion paper that made reference to the potential creation of a Crime Prevention Centre, as well as the need for coordinated crime prevention programs and information in Manitoba, in both the government and voluntary sectors (Government of Manitoba, 1989, pp. 4-5); and in 1993, the Québec Round Table on Crime Prevention Report (Gouvernement du Québec, 1993) suggested a series of measures focusing on a mix of prevention strategies related to situational and social development with a structure to support crime prevention.

\section{The New Directions: Mid-1990s to The Present Day -Toward a National Policy on Crime Prevention}

After the May 1994 decision by Cabinet and before the formal public announcement, work continued in order to finalize the organizational arrangements for the National Strategy including the creation of the National Crime Prevention Council. As one of the key elements of the National Strategy on Community Safety and Crime Prevention (National Strategy) (Government of Canada, 1994d), the Minister of Justice and Attorney General of Canada and the Solicitor General of Canada, Allan Rock and Herb Gray respectively, announced on July 5, 1994 the creation of a 25-member National Crime Prevention Council (NCPC). Professor Ross Hastings of the Department of Criminology, University of Ottawa, was appointed the Council Chair, and Madame Johanne Vallée, Directrice générale, Association des services de réhabilitation sociale, was appointed Vice-Chair. Other members of the newly created council came from a variety of sectors, and included child development experts, community advocates, police officers, lawyers, academics, medical doctors, and business people. All the members were appointed for a three-year term.

The goals of the council, as stated by Professor Hastings, were to, "help governments at all levels coordinate their efforts to prevent crime and reduce victimization, and to help communities develop practical solutions for the problems they face in these areas” (Government of Canada, 1995b, p. 1). A review of the external and internal documentation on the National Strategy (including the July 5, 1994 press release) indicates that this was to be an information gathering clearinghouse, involving public education and a policy development phase. The expectation was that the NCPC 
would work closely with all levels of government to identify trends and successful strategies as well as to propose future directions and priorities. This is exactly what it appears they did. It is also evident that the National Strategy was expected to take a community focus and promote partnerships. Additionally, the National Strategy was to focus on a comprehensive approach in dealing with crime and victimization, one that included community safety, crime prevention, and social development measures.

The level of financial resources allocated to the National Strategy (i.e., \$9.61 million over five years from 1994-95 to 1998-99, including \$5.86 million for Justice Canada and \$3.75 million for the RCMP) was a far cry from the recommendation in the report by the House of Common's Standing Committee on Justice and the Solicitor General in 1993. These resources were primarily meant to support the National Crime Prevention Council (NCPC) and a small secretariat, program or project development, crime prevention conferences, databases, and public information and awareness. Also included were crime prevention seminars and workshops sponsored by the RCMP.

Specifically, the RCMP was responsible for several major community-based programs: Aboriginal Shield Intervention Program (a culturally-based substance abuse prevention program); RCMP Community Suicide Intervention Program (a five-day workshop to help police officers, Aboriginal service providers, and advisors to better assess the risk of suicide and provide intervention); the development of educational materials on dating violence; and holding various workshops aimed at community problem solving (Government of Canada, 1998, p. 4).

The first six months of the National Strategy's work was spent on internal federal consultations, arranged through the Interdepartmental Working Group. This process consisted of consultations with the Federal-Provincial/Territorial Working Group and collecting information on federal crime prevention related activities (Government of Canada, 1994b), along with developing priorities and work plans. The NCPC quickly moved toward defining children and youth as a priority focus in its preventive response to crime. In its first annual report (Government of Canada, 1995a), it stated that interventions at all age levels ( 0 to 6 years, 6 to 12, and 12 to 19 years of age) should be explored with the underlying philosophy that every child is entitled to high-quality and consistent nurturing within a physically secure and emotionally safe environment. It was felt that such an environment would improve each child's opportunity to succeed, reducing the chance of later involvement with the criminal justice system.

The NCPC also identified the need to promote the social and economic benefits that could be gained through Canada's investment in Crime Prevention through Social Development. It decided to devote some energy on what was termed "topical issues in social justice reform”, for example, firearms control, proceeds of crime, and social security review. Finally, while it continued to focus on children and youth, the council voiced its intention to pursue its mission of developing comprehensive communitybased responses to the problems of crime and victimization. A small number of 
“demonstration projects” were funded and a significant consultative network developed.

Several months later, Justice Canada submitted its annual report (Government of Canada, 1995b) on the first year of the National Strategy. This was a Treasury Board of Canada requirement. As the federal centre with the responsibility for crime prevention in Canada, the NCPC Secretariat described the work of supporting various advisory and coordinating bodies to the National Strategy, including its support of the council. It also described work relating to public legal education, communications and consultations, departmental project development, research efforts, and community and Aboriginal policing by the RCMP. In reality, however, most of the energy in the National Strategy was spent on setting up, organizing, and developing a network of experts across Canada.

In the next few years, the NCPC and its Secretariat were active in the following areas: the promotion of Crime Prevention through Social Development; building partnerships; producing a series of policy documents; and producing community-based problem solving and development manuals and tool kits. As well, there was some testing of new intervention models, particularly those involving children and youth. While progress and accomplishments were evident, it became apparent that there were challenges, along with weaknesses in the activities being pursued. The October 1993 Justice Canada Mid-Term Program Evaluation Report indicates, "that [while] the implementation of the National Strategy is on track, this cannot be stated with certainty because there is no real evidence that the performance indicators are used systematically" (Government of Canada, 1994f). Communication and coordination difficulties were also identified within Justice Canada, the federal structure, and at the federal-provincial/territorial level. In short, the focus of the assessment was on the implementation process because the Strategy was really too "young" to generate adequate information about its [program] impact over such a short time period.

A year later, the key message voiced in the NCPC's second annual report was, "that consensus focuses on three issues: the goals of prevention, the means to achieve them, and the delivery strategy most likely to accomplish them" (Government of Canada, 1997). This report reaffirmed the goals of the NCPC, which were to help design a comprehensive and coordinated strategy that would enhance the quality of life, focusing on the safety and security of individuals and their communities. From statements provided in the report, it appears the council was looking to reaffirm its mandate, while at the same time recognize its limitations. The report stated, "However, a great deal remains to be done to translate the rhetoric of prevention into concrete support for community-based prevention initiatives” (Government of Canada, 1997).

In January 1997, a Justice Canada Program Evaluation Report suggested that [surveyed] respondents had indicated that the National Crime Prevention Council had been successful in advising the federal government [on crime prevention]; that it had been successful in its public education and awareness efforts, in setting up a national 
clearinghouse capacity, in promoting multidisciplinary partnerships and in establishing subcommittees to deal with important crime prevention areas. More than half of the council's membership, however, felt the National Strategy did not have access to sufficient resources to do its work effectively. In addition, there remained confusion about the relationship between the council and the National Strategy. This appears evident when we consider the responsibilities of the NCPC in fulfilling the objectives of the National Strategy. During this period the appointments of the council members were reviewed while discussions were also occurring about its mandate.

Notwithstanding the expressed limitations, much was accomplished during these first two and a half years of the National Strategy. It became evident that priority should and would be given to children and youth, as well as to their families, in addition to community-based problem solving and multi-partnership intervention. The "gut feeling" was that the strategy was working, despite the fact that the real evidence of success was not readily available and probably would not be available until a more significant investment was made in developing and implementing comprehensive local crime prevention strategies. This was a key recommendation at the council's final meeting in June 1997.

Accomplishments of the strategy are echoed in the September 1998 Justice Canada Summative Evaluation Report (Government of Canada, 1998). Program evaluators felt that the National Strategy did indeed support an extraordinary amount of work in the area of crime prevention, given the level of funding provided, not to mention the fact that the NCPC had only operated for three years. It appears that they were very successful in developing partnerships and in achieving a consensus on priorities, which included children, youth, and their families, as well as communitydriven programming. More importantly, this was occurring within a social development framework.

Evaluators did find weaknesses in the design of the organizational structure of the strategy, primarily because no one person was charged with the overall responsibility for its success. Also, the role of the NCPC was not clear with respect to the other funded partners and various working groups. In addition, it was felt that the National Strategy made limited use of its performance-measuring framework.

Both the RCMP and Justice Canada were able to leverage internal and external financial and in-kind support for their activities. It is worth mentioning that this program evaluation was conducted after the expansion of the National Strategy into its second phase. More importantly, interest in expanding the National Strategy is observed occurring well before the 1998 Summative Evaluation Report. As the report indicates, it can be traced to the June 1997 Liberal Party of Canada's commitment to the strategy, Securing Our Future Together, along with the subsequent reference to the expansion of the National Strategy in the September 1997 Speech from the Throne. 
For the federal government, this became an opportune time to reconsider and reassess its commitment to crime prevention. One must keep in mind that two Parliamentary Committee Reports - the Justice and the Solicitor General in 1993 and Justice and Legal Affairs in 1997 - had recommended that the federal government allocate to crime prevention measures 1\% (in the former report) and 1.5\% (in the latter report) rising to $5 \%$ of annual federal expenditures to the police, courts, and corrections, insisting that wherever possible such allocation be directed to communitybased crime prevention efforts. Thus, in early 1998, the federal Cabinet reviewed and approved a proposal for a National Strategy on Community Safety and Crime Prevention, Phase II (National Strategy II).

In June 1998, with an initial investment of \$32 million per year over a five-year period, the Government of Canada launched Phase II of the National Strategy. The goal was to build on the work of the National Crime Prevention Council to increase individual and community safety by "equipping Canadians with the knowledge, skills and resources they need to advance crime prevention efforts in their communities" (Government of Canada, 2002). At this time, the National Strategy II was put under the operational responsibility of Justice Canada. This was done through a newly created National Crime Prevention Centre, with an external advisory body called the National Steering Committee, chaired by Barbara Hall.

The National Strategy II was provided with several funding mechanisms: the Community Mobilization Program (the largest of four funds providing grants to communities of no more than \$50,000); the Crime Prevention Investment Fund (providing more significant contributions to implement and evaluate comprehensive community-based crime prevention approaches); the Crime Prevention Partnership Program (providing grants and contributions to support the active involvement of NGOs interested in pursuing community crime prevention activities); and the Business Action Program on Crime Prevention (targeting the professional and business sectors, which currently invest significant resources into crime prevention). A Promotion and Public Education Program was also included in the expanded strategy.

Surprisingly, while the National Strategy II continued to be officially cosponsored by Justice Canada and the MSG, no specific levels of resources were being allocated either to the latter ministry or to the RCMP, as had been the case in the initial phase of the National Strategy. This was corrected, after internal discussions led to a joint memorandum of understanding between the NCPC, Justice Canada, and the MSG including the RCMP. The RCMP would be provided with $\$ 400,000$ a year for three years to promote greater police involvement in, and support for, Crime Prevention through Social Development.

The National Strategy II continued to promote early intervention for children, youth, and their families; but it also broadened policy and program orientations to include greater emphasis on Aboriginal people, and girls and women's personal security. The social development framework and the focus on community-based 
problem solving remained pillars of the strategy in its second incarnation. The need to expand crime prevention efforts and address the root causes of crime was continuously reinforced by Monique Collette, the newly appointed Executive Director of the NCPC. As she herself suggested, "it is only by working with the community that government can truly help in fostering crime prevention environments” (M. Collette, personal communication, 2002) ${ }^{2}$.

In short, the strategy was designed to prevent crime by encouraging multipartnership approaches, community-based problem solving, and to increase public awareness of effective social development approaches to crime prevention. A review of various press releases and related documents indicates that the expansion inherent in National Strategy II was viewed as contributing to the government's overall priorities of children, youth, Aboriginal communities, women's personal security, as well as to the government's social and economic union initiatives. Federal officials also felt that sufficient linkages had been made to other programs (the National Children's Agenda, the Family Violence Initiative, the Youth Employment Strategy, the Young Offenders Program, and Aboriginal Head Start, to name a few).

Whether feasible or not, federal officials affirmed that departmental linkages would ensure that duplication of funding would not occur and that crime prevention objectives would be integrated within other programs, with the lead role to be taken by other federal departments. As previously mentioned, these considerations serve to reinforce a previous observation, namely, that while lead responsibility for crime prevention was assigned to Justice Canada and the MSG, this did not negate the fact that other federal departments were also involved in activities related to crime prevention, some to a significant extent.

One of the unique characteristics of the National Strategy II is that the provinces and territories played a significant decision-making role related to project funding. This was particularly the case with the Community Mobilization Program. In addition, a great number of projects were funded over the following two and a half years. In fact, by the end of 2000, more than 1,300 projects, located in over 450 communities across Canada, had received federal funding. Given this significant financial investment, it is more than appropriate to find out whether this phase of the strategy actually met the expectations of the Parliamentary Committees, the members of the previous National Crime Prevention Council, the Government of Canada, and most importantly, the individuals, neighbourhoods, and communities most affected by crime and victimization.

The January 2001 Justice Canada mid-term evaluation provides insight into the impact of Phase II activities. For example, evaluators found widespread support among key stakeholders. Further, the Canadian public was being informed about crime prevention through a social development approach, as advocated by the National Strategy. Grants and contributions to local community efforts were viewed as an 
appropriate means to provide support for community mobilization and problem solving efforts. Moreover, the evaluation acknowledged that an immense amount of work had been accomplished over the first two and a half years of the second phase of the National Strategy. On the downside, the report suggests that the National Strategy needed to better tailor the strategies and resources required for high need, low capacity communities and for those communities whose first language is neither English nor French (Government of Canada, 2001) ${ }^{3}$. As well, the important issue of program and community sustainability was raised as a key challenge for the National Strategy. The issue of further investing in the National Strategy's organizational structure in order to bring services closer to communities and to facilitate the gathering, monitoring, and dissemination of information pertaining to the ongoing performance of the strategy was discussed and emphasized. The program evaluators concluded their assessment by stating that:

The National Strategy has accomplished a great deal to date. The focus of its efforts during the reminder of its five-year agenda will be to improve on its current operations, to enhance ongoing monitoring and evaluation of its work, to tailor its activities to targeted groups and communities, and to capitalize better on what it has learned to ensure its ongoing development. (Government of Canada, 2001)

The Government of Canada, however, was already assessing the need to further increase the resources provided through the National Strategy II. It appears from the official public documentation available, that the "overwhelming success" of the National Strategy, the continuing need for new crime prevention efforts, and the advancement of knowledge about crime prevention was the rationale for the Government of Canada's decision (officially announced in July 2001) to invest an additional \$145 million over four years (2001-2005) in Phase II of the initiative. Take note that the government had previously indicated its commitment to expand the National Strategy for Community Safety and Crime Prevention in its 2001 Speech from the Throne. The Liberal Plan for the Future of Canada indicated its commitment to gradually increase funding for the National Strategy by \$145 million over four years. This time, the MSG and the RCMP received a small portion of the new resources, totalling \$5.6 million or 4\% of the \$145 million over four years. The 2003 Building Safer Communities Publication entitled, NCPS Highlights: Building on Progress, Charting the Future (Government of Canada, 2003, p. 2) suggests three key priorities:

- Promoting the integrated action of key governmental and non-governmental partners to reduce crime and victimization;

- Assisting communities in developing and implementing community-based solutions to problems that contribute to crime and victimization, particularly as they affect children, youth, women and Aboriginal people; and

- Increasing public awareness of, and support for, effective approaches to crime prevention. 
This second thrust of the National Strategy II encouraged the development and implementation of numerous activities and initiatives. For example, the NCPS Highlights document (Government of Canada, 2003) indicates that the National Strategy supported activities in over 780 communities and funded approximately 45 large-scale projects and their evaluations. In addition, the National Strategy had also engaged in the development of knowledge in several areas such as bullying and schoolbased anti-violence. In a recent article, Léonard, Rosario, Scott, and Bressan (2005) discuss the numerous lessons learned from the National Strategy's funded activities. The authors highlight the many challenges of community-based initiatives and their related effectiveness. They further suggest:

Because of challenges in program implementation (maintaining a random assignment, retention and attrition rates of participants, program monitoring) and evaluation of community-based projects (associated with the quality of program implementation and difficulties in securing the involvement of participants), it is often difficult to assess whether projects produce or sustain their impacts or effectiveness over the long term. (p. 242)

During that period, it appeared increasingly clear that the National Strategy pursued stated objectives, but with a renewed interest in the application of knowledge and evidence-based intervention. More specifically, as indicted by Leonard et al. (2005):

It is also clear that a national strategy must chart a strategic course in crime prevention and community safety and that it must have a resource commitment that undergirds a will to develop and utilize evidence-based knowledge and the determination to reflect and respond to arising political and policy challenges. (p. 246)

Finally, from what little information is available, it appears that the advent of the Harper Government is having a significant impact on the National Strategy's direction, for example through an increased focus on issues such as drug-related crime, youth gangs, and gun violence. We should note that several years ago the National Strategy was the subject of a review by the federal Cabinet and by Treasury Board but little has officially transpired from this review with the exception of a few new areas of interest being identified for consideration, i.e., youth gangs and gun violence. Parallel to this review process, the National Crime Prevention Centre invested time and effort in a strategic review process in the fall of 2006. The results of this review were made public in 2007 through a reformulation of the NCPC mission statement by Public Safety Canada (PSC) via its website, which now indicates that, as of December 6, 2009, the "NCPC's mission is to provide national leadership on effective and cost-efficient ways to both prevent and reduce crime by addressing known risk factors in high-risk populations and places." 4 
Further, PSC states that, "to achieve its mission, the NCPC develops policies; gathers and disseminates knowledge to Canadian communities; and, in cooperation with the provinces and territories, manages funding programs that support community crime prevention projects through time-limited grants and contributions" (Government of Canada, 2009, p. 1). In 2008, the budget for ongoing funding of crime prevention was \$30 million, which means that the Government of Canada "effectively doubles the National Strategy's permanent funding base to \$63 million per year” (Government of Canada, 2009, p. 1).

It appears that the major changes that have occurred since the Harper Government came to power have been to focus the NCPC's effort on funding and evaluating interventions to prevent and reduce offences among those most at risk with an emphasis on issues such as drug-related crime, youth gangs, and gun violence. As well, the emphasis is on supporting crime prevention interventions that have been shown to be effective through research. While investing significant resources in evidence-based crime prevention interventions appears to be an appropriate strategy, it does represent a significant departure from previous community safety and crime prevention efforts. Importantly, it will limit financial support to communities who wish to test out new ideas and approaches directed toward their particular needs, as well as potentially limit the traditional support provided through the National Strategy to communities in need of capacity building if they are unable to put in place "proven crime prevention programs”. This is particularly true for northern and isolated communities as well as inner-city neighbourhoods faced with major socio-economic and crime problems.

\section{Discussion and Conclusion}

Canada's efforts in crime prevention emerged slowly with early activities focused on the enforcement of statutes and existing laws. From the late 19th century to the latter part of the 1930s, crime prevention consisted primarily of activities spearheaded by the RCMP. During the 1930s, crime prevention was associated with acquiring new equipment and technology to help in the enforcement of statutes, particularly with respect to reducing or eliminating "rum-running”. By the 1940s, prevention efforts were marked by three themes: the prevention of delinquency; the prevention of sabotage and the counterfeiting of money, gas and food coupons; and post-war prevention and detection of Soviet espionage.

During the 1950s and 1960s, general crime prevention took a back seat to prevention-related activities focusing on drug trafficking, organized crime, white-collar crime, spies, politics, and security. However, the National Conference on the Prevention of Crime held in 1965 at the University of Toronto, drew attention to the role of the community in dealing with crime and its prevention.

Throughout the 1960s and into the 1970s, preventive efforts continued to emphasize the enforcement of statutes and laws especially with respect to the RCMP. 
At the same time, however, the creation of the Correctional Consultation Centre in 1968-69 signalled the beginning of a growing recognition of the importance of the social causes of crime. As well, this period was one in which there was a growing awareness of the role of the police in activities beyond enforcement. In addition, children and youth were often the focal point of prevention strategies.

By the early 1980s, crime prevention began to emerge as an important topic in the academic and law enforcement literature, and notions of social development began to gain support. During the early 1990s, the National Crime Prevention Council (NCPC) was established, beginning a process where national attention was paid to crime prevention in Canada. The initial success of the NCPC led to continued support and the announcement of Phase II of this initiative. At the same time, a social development approach gained popularity and national support. This was emphasized in the approval of Phase II of the Initiative by the federal Cabinet, which provided an additional \$90 million over three years. While, the fundamental pillars of the initiative remained intact (namely, community partnerships, high-risk populations including children and youth, and social development), increased emphasis was placed on encouraging more comprehensive interventions that include more short- and medium-term prevention strategies. As well, there was support for the development of inclusive community governance structures and the application of knowledge-based intervention strategies.

In more recent years, we observe an increasing attention to high-risk behaviour such as youth gangs and gun violence on the part of the federal government and on implementing and evaluating the impact of proven crime prevention programs.

This brief history of crime prevention efforts in Canada shows a clear trajectory from the mid-1980s onward, toward support for more comprehensive and integrated community-based crime prevention activities. The interventions are increasingly aimed at community safety, health, and well-being, while involving the police, other service providers, as well as community members in the process.

The future of crime prevention activity in Canada will no doubt build on this rich history. The development of policy in this area will include the need to be accountable for the resources devoted to crime prevention activities. This will require acceptance of an evidence-based intervention philosophy and the ongoing use of thorough and systematic evaluations to assess the long-term viability and effectiveness of the crime prevention activities undertaken. Moreover, crime prevention efforts will need to demonstrate that they are addressing the concerns of key stakeholders regarding questions of crime and victimization in Canadian communities. At the present time, there is widespread support among the public and the police community for crime prevention activities that address the root causes of crime through a social development approach. Whether this continues in the future will depend upon the effectiveness of the actions of stakeholders and policy-makers in addressing this issue of vital concern to Canadian society. 


\section{References}

Bennett, R. B. (1933, July). RCMP Quarterly, 1(1).

Binham, L. (1940, April). RCMP Quarterly, 7(4).

Canadian Council on Social Development and Canadian Criminal Justice Association. (1987). Crime prevention through social development: A national workshop report (p. 1). Ottawa: Author.

Canadian Council on Social Development. (1990). Safer communities: An emerging Canadian experience (p. 8). Ottawa: Author.

Centre of Criminology. (1965). National conference on the prevention of crime: Report of the proceedings (May 31st to June 3rd). Toronto: University of Toronto.

Doherty, P. (1986). Crime prevention research in the Ministry of the Solicitor General of Canada. (User Report No. 1986-54). Ottawa: Solicitor General of Canada.

Government of Canada. (1925). Annual report of the Royal Canadian Mounted Police. Ottawa: Author.

Government of Canada. (1961). The commissioner's annual report. Ottawa: Royal Canadian Mounted Police.

Government of Canada. (1967). Annual report of the Royal Canadian Mounted Police. Ottawa: Author.

Government of Canada. (1971). Annual report of the Ministry of the Solicitor General of Canada for fiscal year 1970-71. Ottawa: Author.

Government of Canada. (1973). Annual report of the Ministry of the Solicitor General of Canada for fiscal year 1972-73. Ottawa: Author.

Government of Canada. (1976). Peace and security program communications package, February 4, 1976. Ottawa: Solicitor General of Canada.

Government of Canada. (1977). Annual report of the Royal Canadian Mounted Police for fiscal year 1976-77. Ottawa: Author.

Government of Canada. (1986a). Evaluation of the crime prevention initiative, 19741985, January 14, 1986 (Office of Audit and Evaluation, Ministry Secretariat, Corporate Systems). Ottawa: Solicitor General of Canada. 
Government of Canada. (1986b). Report on the evaluation of the crime prevention initiative, 1974-1985 (Ministry Secretariat, Corporate Systems). Ottawa: Solicitor General of Canada.

Government of Canada. (1986c). The Solicitor General's program of crime prevention (Internal report dated September 10, 1986 by the Programs Branch). Ottawa: Solicitor General of Canada.

Government of Canada. (1993a). Foreword of the proceedings, March 10-12, 1993. National Symposium on Community Safety and Crime Prevention. Ottawa: Justice Canada.

Government of Canada. (1993b). Draft paper on safety and security through crime reduction and prevention. (Police \& Security Branch). Ottawa: Secretariat of the Solicitor General of Canada.

Government of Canada. (1993c). Crime prevention in Canada: Toward a national strategy. (Standing Committee on Justice and the Solicitor General of Canada. The Horner Committee Report). Ottawa: House of Commons.

Government of Canada. (1994a). Discussion document on the proposed terms of reference for the interdepartmental committee on crime prevention. Ottawa: Author.

Government of Canada. (1994b). Outline of the national strategy on community safety and crime prevention. Discussion document presented by the FederalProvincial/Territorial Working Group, March 22-24, 1994, seeking the approval of the Ministers Responsible for Justice for the final development of a national strategy on the basis of the action plan proposed in said paper. Ottawa: Author.

Government of Canada. (1994c). National strategy on community safety and crime prevention: An evaluation framework (Program Evaluation Section). Ottawa: Justice Canada.

Government of Canada. (1994d). National Crime Prevention Council created. (News Release, July 5, 1994). Ottawa: Author.

Government of Canada. (1994e). Roadmap of federal activities relating to crime prevention. A document assembled in September 1994 to provide an overview of federal activities relating to crime prevention and community safety. Ottawa: Author

Government of Canada. (1994f). Mid-term program evaluation report on the national strategy on community safety and crime prevention. (October 1993, Evaluation Section, Research, Statistics and Evaluation Directorate). Ottawa: Justice Canada. 
Government of Canada. (1995a). First annual report of the National Crime Prevention Council (December 1995). Ottawa: Justice Canada.

Government of Canada. (1995b). Annual report of the national strategy on community safety and crime prevention for 1994-95 (May-June 1995). Ottawa: Justice Canada.

Government of Canada. (1997). Mobilizing for action: The second annual report of the National Crime Prevention Council (June 1997). Ottawa: Justice Canada.

Government of Canada. (1998). Summative evaluation of the national strategy on community safety and crime prevention, September 30, 1998 (Program Evaluation Section). Ottawa: Justice Canada.

Government of Canada. (2001). Mid-term evaluation of the national strategy on community safety and crime prevention, Phase II (Technical Report, Evaluation Division, Policy Integration and Coordination). Ottawa: Justice Canada.

Government of Canada. (2002). Phases of the national crime prevention strategy (Information taken from summary document on the National Strategy's website). Ottawa: Justice Canada. Retrieved from http://www.publicsafety.gc.ca/res/cp/res/ssincps-amosnpc-eng.aspx

Government of Canada. (2003). National crime prevention strategy highlights: Building on progress, charting the future. Ottawa: Public Safety and Emergency Preparedness Canada. Retrieved from http://www.publicsafety.gc.ca/res/cp/res/ssincps-amosnpc-eng.aspx

Government of Canada. (2009). National crime prevention strategy: Support the successful implementation of the national crime prevention strategy. Ottawa: Public Safety Canada. Retrieved December 6, 2009 from http://www.publicsafety.gc.ca/res/cp/res/ssincps-amosnpc-eng.aspx

Government of Manitoba. (1989). An integrated approach to crime and victim assistance: A discussion paper. Winnipeg, MB: Attorney General of Manitoba.

Government of New Brunswick. (1997). Crime prevention in New Brunswick: A summary of initiatives. Fredericton, NB: Solicitor General of New Brunswick.

Gouvernement du Québec. (1993). Pour un Québec plus sécuritaire: Partenaires en prévention. Rapport de la Table ronde sur la prévention de la criminalité. Québec, PQ: Ministère de la sécurité publique du Québec 
Griffiths, C., \& Verdun-Jones, S. (1994). Canadian criminal justice (2nd ed.). Toronto: Harcourt Brace \& Company, Canada Inc.

Hastings, R. (1991). An inventory of crime prevention and community policing projects 1974-1991 in Canada (Final Report, Vol. 1). Ottawa: Solicitor General of Canada.

Hofley, B. C. (1975). Presentation of the federal position. In D. Macfarlane (Ed.), Second national crime prevention workshop: Report of the proceedings, May 2122, 1975. Toronto: Centre of Criminology, University of Toronto.

Kelly, N., \& Kelly, W. (1973). The Royal Canadian Mounted Police: A century of history (1873-1973). Edmonton, AB: Hurtig Publishers.

Léonard, L., Rosario, G., Scott, C., \& Bressan, J. (2005). Building safer communities: Lessons learned from Canada's national strategy. Canadian Journal of Criminology and Criminal Justice, 47(2), 233-250.

Liberal Party of Canada. (1993, April 22). Crime prevention and urban safety (Announcement of a crime and justice policy package). Ottawa: Author.

Macfarlane, D. (Ed.). (1975). Second national crime prevention workshop: Report of the proceedings, May 21-22, 1975. Toronto: Centre of Criminology, University of Toronto.

Moore, E. R. (1945, October). RCMP Quarterly, 11(2).

Moore, E. R. (1946, January). RCMP Quarterly, 11(3).

Vernon, M. H. (1936, January). RCMP Quarterly, 3(3).

Watson, G. (1975). Foreword to the report of the proceedings. In D. Macfarlane (Ed.), Second national crime prevention workshop: Report of the proceedings, May 2122, 1975. Toronto: Centre of Criminology, University of Toronto.

Wilson, D. J. (1942, January). RCMP Quarterly, 9(3). 


\section{Endnotes}

${ }^{1}$ The Ministry of the Solicitor General of Canada and its Departmental Headquarters were created in fiscal year 1966-67. The Departmental Headquarters was replaced by the Ministry Secretariat in fiscal year 1973-74.

${ }^{2}$ This quote was provided by Ms. Monique Collette at the request of the author to help summarize her thinking around the role of government in crime prevention.

${ }^{3}$ In the January 2001 Program Evaluation Report, reference is made to the fact that "for the purposes of this evaluation, the term 'high needs communities' is used to refer to communities at risk that possess limited resources and capacity for change and that are isolated or marginalized from the mainstream society due to geography (rural/remote locations) and/or due to a combination of socio-economic and cultural factors."

${ }^{4}$ Public Safety Canada. National Prevention Crime Centre. 2007. A Blueprint for Effective Crime Prevention. Ottawa: Public Safety Canada. 
